\title{
Effect of food lures for monitoring of Anastrepha fraterculus (Diptera: Tephritidae) in Acca sellowiana (Myrtaceae)
}

\author{
Efecto de atrayentes alimenticios para el monitoreo de Anastrepha fraterculus (Diptera: Tephritidae) en \\ Acca sellowiana (Myrtaceae) \\ JOATAN MACHADO DA ROSA ${ }^{1}$, CRISTIANO JOÃO ARIOLI², ALINE COSTA PADILHA², \\ LENITA AGOSTINETTO ${ }^{4}$ and MARCOS BOTTON 5
}

\begin{abstract}
The South American fruit fly, Anastrepha fraterculus (Diptera: Tephritidae) stands out for its polyphagous habit of damaging the production of several fruits in southern Brazil. This study aimed to evaluate the capture efficiency of $A$. fraterculus using grape juice at different periods of decomposition and aging as well as to test the capture efficiency of the enzymatic hydrolyzed protein Cera Trap ${ }^{\circledR}$ in feijoa crops. The work was conducted in a commercial feijoa orchard in São Joaquim, SC, Brazil during the 2014 growing season. Undiluted Cera Trap ${ }^{\circledR}$, fresh grape juice and grape juice that had aged for 7 and 14 days were evaluated. All of the treatments with grape juice were used at the recommended concentration of $25 \%$. McPhail traps were used with $300 \mathrm{~mL}$ for each lure. On a weekly basis, the number of adults and the percentage of female fruit flies captured were evaluated, using identification and counting. Cera Trap ${ }^{\circledR}$ was the lure that captured the highest number of fruit flies, with a high percentage of females and with a higher frequency of captures during the season. Cera Trap ${ }^{\circledR}$ also showed the highest number of action thresholds compared to grape juice treatments. The $25 \%$ fresh and aged grape juice showed a low number of captures and a low number of action thresholds. We conclude that fresh and aged grape juice were not effective for capturing and monitoring A. fraterculus in feijoa orchards. The Cera Trap ${ }^{\circledR}$ lure proves to be an alternative to improve monitoring of $A$. fraterculus in orchards in southern Brazil.
\end{abstract}

Key words: Monitoring, fruit fly, control index, attractiveness, pest management.

Resumen: La mosca suramericana de las frutas Anastrepha fraterculus (Diptera: Tephritidae) se destaca por su hábito polífago, dañando la producción de diversas frutas en el sur de Brasil. El objetivo de este estudio fue evaluar la eficacia de la captura de moscas de la fruta utilizando jugo de uva en diferentes estados de descomposición y envejecimiento, así como evaluar la eficiencia de la captura de A. fraterculus con la proteína hidrolizada de origen animal Cera Trap ${ }^{\circledR}$ en un huerto de Acca sellowiana. El trabajo fue realizado en São Joaquim, SC, Brasil, durante la fructificación de 2014. Los tratamientos fueron: Cera Trap ${ }^{\circledR}$ sin diluir y jugo de uva fresco o envejecido durante 7 y 14 días. Los tratamientos con jugo de uva fueron utilizados a una concentración del $25 \%$. Se utilizaron trampas McPhail que contenían $300 \mathrm{~mL}$ de cada atrayente. Se evaluaron semanalmente el número de moscas adultas de las frutas y el porcentaje de hembras capturadas mediante el recuento e identificación de las especies. Cera Trap ${ }^{\circledR}$ fue el atrayente con el mayor número y mayor porcentaje de hembras de moscas capturadas, y de mayor frecuencia de capturas durante la estación proporcionando más posibilidades de control en comparación con los tratamientos que contenían jugo de uva. Se concluye que los jugos de uva fresca o envejecidos no fueron eficaces en la captura y monitoreo de $A$. fraterculus en huerto comercial de feijoa. El atrayente Cera Trap ${ }^{\circledR}$ demostró ser una alternativa para mejorar el monitoreo de $A$. fraterculus en huertos de feijoa.

Palabras clave: Monitoreo, moscas de las frutas, instrucción de control, atracción, manejo de plagas.

\section{Introduction}

Acca sellowiana (Berg) Burret (Myrtaceae) (feijoa) is a native fruit species found in the highland regions of the States of Rio Grande do Sul and Santa Catarina in Brazil as well as in the northern part of Uruguay and Argentina (Thorp and Bieleski 2002). Its fruits have an exotic flavor and aroma. The fruit presents great economic potential as a result of the presence of antimicrobial agents and its bioactive, antiinflammatory, and antioxidant properties (Weston 2010) as well as its antidepressant properties (Mahmoudi et al. 2015). Although feijoa is native to southern Brazil, countries such as Uruguay and Argentina, Colombia, the United States, France, Italy, New Zealand (Thorp and Bieleski 2002) and recently China (Zhang et al. 2010) commercially produce the fruit and its derivatives. In Brazil, new perspectives to increase production are being outlined (Ducruquet et al. 2008) with the launch of four commercial feijoa cultivars in the State of Santa Catarina.

Feijoa orchards are damaged by different insect pests, especially the South American fruit fly, Anastrepha fraterculus (Wiedemann, 1830) (Rosa et al. 2013). This species has a Neotropical origin and can be found from the Southern United States to northern Argentina (Malavasi et al. 2000). Anastrepha fraterculus has a widespread presence in the commercial crops of feijoa as well as in natural forests. Moreover, it is considered to be the main pest of feijoa and it can infest up to $100 \%$ of the fruit in orchards without control (Luckmann et al. 2009; Rosa et al. 2013).

\footnotetext{
${ }^{1}$ Dr. Laboratory of Entomology. Santa Catarina Estate University, Agronomy Department, 88520-000, Lages, SC, Brazil. joatanmachado@gmail.com, corresponding author. ${ }^{2}$ Dr. Laboratory of Entomology. Agricultural Research and Rural Extension - Epagri, 88600-000. São Joaquim, SC, Brazil. ${ }^{3}$ M. Sc. Laboratory of Entomology. Federal University of Pelotas, Plant Protection Department, 96010-900, Pelotas, RS, Brazil. ${ }^{4}$ Dr. Graduate Program in Environment and Health. University of Planalto Catarinense, 88509-900, Lages, SC, Brazil. ${ }^{5}$ Dr. Laboratory of Entomology. Brazilian Agricultural Research Corporation - Embrapa, 95701-008. Bento Gonçalves, RS. Brazil.
} 
A key strategy for fruit fly management programs is to monitor the pest at the orchard level. In this sense, the availability of lures and traps is essential for defining the right moment for the control of the fruit flies in orchards. Several lures used for monitoring fruit flies are currently available, varying in type depending on fruit fly species, country, and location (Botton et al. 2012). Throughout the years, efforts have been directed toward identifying other readily available, low cost materials, which could be used locally by farmers (Epsky et al. 2014). In the South region of Brazil, $25 \%$ grape juice is the lure recommended as the standard for capturing fruit flies in apple orchards (Kovaleski and Ribeiro 2002; Kovaleski 2004), and this information has been expanded to other crops such as grape, peach, plum and feijoa.

According to Kovaleski and Ribeiro (2002), Nora and Hickel (2002) and Muller et al. (2013), fruit fly control should start when a level of 0.5 flies per trap per day is reached. However, in recent years, there have been significant failures in the control of $A$. fraterculus in several orchards, even with the use of monitoring (Botton et al. 2012). One of the main reasons for this problem is connected to the inefficiency of some lures that are not capable of detecting the presence of the pest in orchards (Botton et al. 2013). This fact results in damage to production, whereby the fruit fly is present in the orchard, but not captured in the traps, as it is baited with inefficient lures.

During the decomposition of organic substances such as fruit juice, the release of secondary compounds is necessary. According to Heath et al. (1993), Salles (1999) and Nascimento et al. (2014), this fact can positively influence the capturing of fruit flies of the genus Anastrepha. Odor perception of insects, including fruit flies, was elucidated by Visser (1986), who demonstrated that most adult insects are attracted by specific (groups of) odors, which can be released during decomposition.

Despite the availability of various hydrolyzed proteins with proven efficiency for monitoring $A$. fraterculus ( $\mathrm{Scoz}$ et al. 2006; Teixeira et al. 2010; Botton et al. 2012; Lasa et al. 2015), many fruit growers still choose to use $25 \%$ grape juice. This is due, hypothetically, to old recommendations, because grape juice is easily available in the market and has a lower cost compared to hydrolyzed proteins.

The hydrolyzed protein of animal origin $\left(\right.$ Cera Trap $\left.{ }^{\circledR}\right)$ was recently introduced to the Brazilian market for monitoring and controlling fruit flies. Cera Trap ${ }^{\circledR}$ is produced through the enzymatic hydrolysis of the intestinal mucosa of swine (Sierras et al. 2006) and causes the emission of volatiles, especially amines and organic acids, which are highly attractive primarily to tephritid females (Marín et al. 2006). One of the major advantages of this new hydrolyzed protein is its stability, as the attractiveness to adults is maintained over a period of 60 days without the need to exchange more than the evaporated content (Machota-Junior et al. 2013). Lasa and Cruz (2014), Lasa et al. (2015) emphasize the practicality of its use and the selectivity on other insects as well as the economic viability of this lure.

According to Botton et al. (2012), monitoring should provide information that adequately represents the behavior of the $A$. fraterculus population in orchards. In addition, reduced lure longevity and low capture rates for adult fruit flies may compromise monitoring and thereby increase the costs of monitoring programs (Lasa et al. 2014).

Therefore, the search for better and more efficient lures for each crop and region should be performed constantly to ensure that the observed capture rates of the traps properly correspond to the actual populations of fruit flies present in orchards. In this study, we evaluate for the first time under field conditions, the commercial hydrolyzed protein Cera Trap $^{\circledR}$ and the different aging combinations of grape juice for the capture of $A$. fraterculus adults in feijoa orchard.

\section{Materials and methods}

Description of the study area: The work was performed in an 18-year old feijoa orchard located at the Experimental Station for Agricultural Research and Rural Extension of Santa Catarina (EPAGRI), São Joaquim, SC, Brazil, at $28^{\circ} 17^{\prime} 39^{\prime \prime} \mathrm{S}$ and $49^{\circ} 55^{\prime} 56^{\prime} \mathrm{W}$, at an altitude of 1,415 m (Fig. 1). The local climate is $\mathrm{Cfb}$, mesothermal, according to Köppen's classification, which means it is moist without a dry season, with fresh summers $\left(22^{\circ} \mathrm{C}\right)$ and an annual average

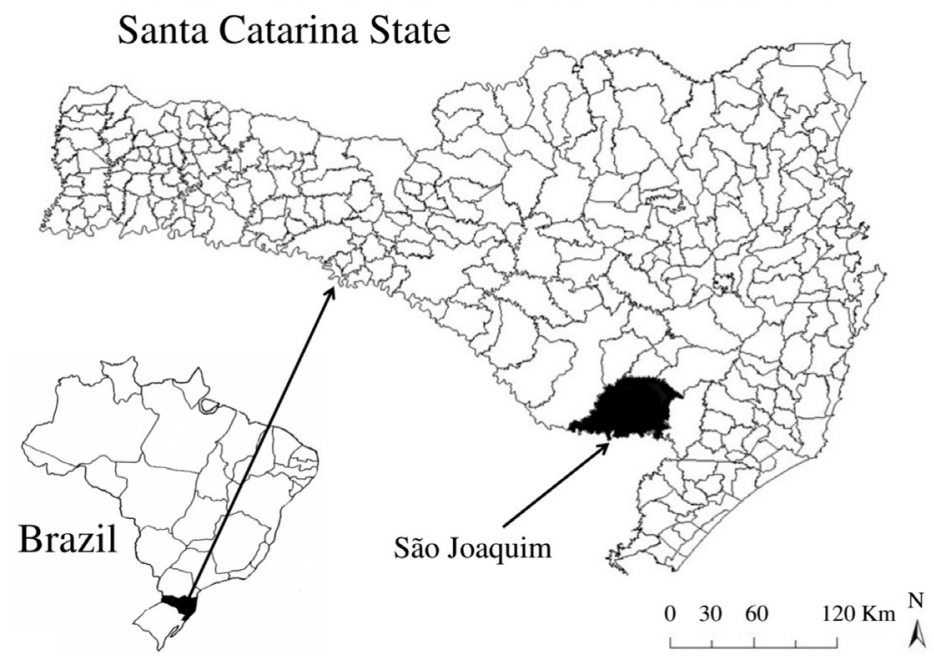

Figure 1. Thematic map of the region of São Joaquim, Santa Catarina, Brazil. Illustration developed using the cartographic database of the Brazilian Institute of Geography and Statistics. 
temperature of $13.5{ }^{\circ} \mathrm{C}$. The experiment was performed during the 2014 production cycle, comprising the fruiting period (January to May). The orchard had a rectangular form measuring 1.5 ha spaced with three meters between the plants and five meters between the rows. The orchard is surrounded by native fields, urban areas, Pinus reforestation areas, and natural forest remnants (Araucaria Forest).

Lures and traps. Four food baits with Mcphail traps were compared in the field: a) Hydrolyzed protein Cera Trap ${ }^{\circledR}$, Bioiberica (Barcelona, Spain), undiluted, replacing only the volume lost through evaporation; b) Fresh grape juice (Embrapa Uva e Vinho, Bento Gonçalves, RS); c) Grape juice aged for 7 days; d) Grape juice aged for 14 days. Distilled water was used as a control. Treatments with grape juice were diluted in the recommended dose of $25 \%$ and aged in the recipients covered by a voile type fabric, packed under field environmental conditions, but protected from the sun and rain during the aging period.

For all lures, we used a commercial Mcphail Trap (Isca Technologies, Iují, RS) baited with $300 \mathrm{~mL}$ of each lure. The traps were hung in trees at a distance of $15 \mathrm{~m}$ apart and were rotated within the block every week. The number of fruit flies captured was counted every 7 days for 14 consecutive weeks. The collection of flies, cleaning of the traps, and rotation within the block were performed every 7 days, along with the changing of the bait (grape juice lures) and the replacement of the evaporated volume in the Cera Trap ${ }^{\circledR}$ treatment.

Insects. The fruit flies caught in the trap were separated from the bait solution through a sieve and placed in $80 \mathrm{~mL}$ plastic vials containing $70 \%$ ethanol. Then, the samples were screened, sex was determined, and samples were identified and counted in the laboratory. The identification of the genus Anastrepha was based on morphological characters; observation of standard wings, thorax, and female aculeus morphology (Alberti et al. 2012) as well as on the taxonomic keys developed by Steyskal (1977) and Zucchi (2000).

Statistical analysis. The experiment was carried out in a randomized complete block design. For the evaluation of the lures, the number of captured $A$. fraterculus was transformed to the average number of flies per trap per day (FTD). The FTD values and the percentage of females per trap session were transformed into $\sqrt{ }(x+1.0)$ to stabilize variance. The data were analyzed using ANOVA, and the means were compared by Tukey's test $(\mathrm{P}<0.05)$ using the software $\mathrm{R}(\mathrm{R}$ Development Core Team 2012).

\section{Results and discussion}

During the production cycle, a total of 210 Tephritoidea individuals were captured, of which 209 (99.9\%) belonged to the species $A$. fraterculus; $57.4 \%$ were females and 42.6 $\%$ males, thereby confirming the previous results that showed this species as the dominant one in the region (Teixeira et al. 2010; Rosa et al. (2013). In the neighboring State of Rio Grande do Sul, Kovaleski et al. (2000), Scoz et al. (2006) and Nunes et al. (2013) also found similar percentages of prevalence of the same species. The other captured species was Anastrepha dissimilis Stone, a species associated with passiflora fruits (Zucchi 2007). The capture of this species in feijoa orchards is possibly due to the presence of native passion fruits (Passiflora spp.) near the area of study.

The hydrolyzed protein Cera Trap ${ }^{\circledR}$ presented the highest number of $A$. fraterculus captured during the evaluation period $(59.8 \%)$. The fresh grape juice had the second highest capture rate $(20.6 \%)$, while grape juice with aged 7 and 14 days showed $13.9 \%$ and $5.7 \%$, respectively. These results are similar to those of Herrera et al. (2016), who showed that Cera $\operatorname{Trap}^{\circledR}$ was the most efficient lure for capturing Anastrepha flies when compared to different commercial grape products in several experiments in fruit orchards in Mexico.

The FTD values in grape juice treatments were significantly lower compared to Cera Trap ${ }^{\circledR}$ during the season $(\mathrm{F}=7.83 ; \mathrm{df}=4,20 ; \mathrm{P}>0.0001)$ (Table 1) and (Fig. 2). The percentage of females caught in the McPhail traps was significant $(\mathrm{F}=15.38 ; \mathrm{df}=4,20 ; \mathrm{P}>0.0001)$. Grape juice tested with 14 days of aging showed the higher capture of females $(66.6 \%) 1{ }^{\pi}: 2 \%$. However, this lure presented a small number of total flies captured during the season (5.7 $\%)$ and a low FTD index $(0.12 \pm 0.04)$, and it did not differ from the control treatment (Table 1). Although there was no significant difference for fresh juice $(48.8 \%)$ and juice aged for 7 days $\left(44.8 \%\right.$ ), Cera Trap $^{\circledR}$ also had a high percentage of captured females $(61.6 \%)$ (Table 1$)$, with a sex ratio of 1 : 1.6 ․ Similarly, Herrera et al. (2016) and Lasa et al. (2015),

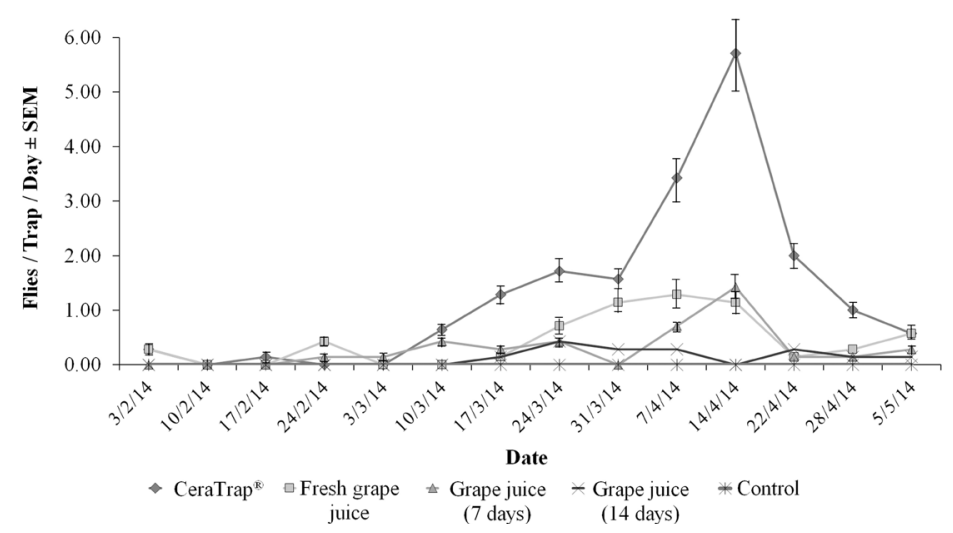

Figure 2. Weekly evaluation of Anastrepha fraterculus $(\mathrm{FTD} \pm \mathrm{SEM})$ in a feijoa orchard monitored with McPhail traps baited with Cera Trap ${ }^{\circledR}$ and grape juice at different ages. A.t: Action threshold. 
respectively, captured $77.06 \%$ and $76.1 \%$ of Anastrepha ludens (Loew) females in traps baited with Cera Trap ${ }^{\circledR}$ in citrus orchards.

In general, after emergence, $A$. fraterculus adults, especially females, need protein sources to ensure their fertility (Heath, 1993). Furthermore, the high attractiveness of protein derivatives for $A$. fraterculus females may be associated with the need for the intake of amino acids preceding egg production and the generation of fertile offspring (Zucoloto 2000; Nunes et al. 2013). According to Cangussu and Zucoloto (1997), fruit fly females that feed with high protein levels are more receptive to copulation compared to females that receive a diet with a lower content of these substances. Therefore, there is generally a larger number of female captures in traps baited with protein attractants.

Despite the fact that the sex ratio is not considered for decision-making about control in Brazil, the large number of trapped females is a positive factor, as they are responsible for oviposition and puncture which cause damage to fruits. In addition, higher percentages of females trapped are desirable in the development of mass trapping programs.

According to Monteiro et al. (2007), the attraction exerted by proteins is higher when compared to juice attractants in McPhail traps. Contrarily to the results found by Salles (1999), our study did not show a better effect for the capture of $A$. fraterculus with the aging grape juice (Table 1). As reported previously by Salles (1999), the aging and decomposition of food attractants such as red wine vinegar $(25 \%)$ and peach juice $(10 \%)$ showed a direct relationship with an increasing number of captured flies belonging to the Anastrepha genus (especially A. fraterculus) in peach orchards (Prunus persica L.). However, this relation was not found in the feijoa orchard.

For the majority of temperate climate fruits grown in the South region of Brazil, fruit fly control should start when a level of 0.5 flies per trap per day is reached (Kovaleski and Ribeiro 2002; Nora and Hickel 2002; Muller et al. 2013). In this aspect, Cera Trap ${ }^{\circledR}$ was the most efficient, presenting a greater number of action threshold ( $>0.5$ FTD), even in periods with a lower density of the $A$. fraterculus population compared to fresh or aged grape juice (Table 1).

The greatest occurrence period of $A$. fraterculus, measured in the orchards, begins when the feijoa fruit reaches the critical size to receive the postures, approximately $30 \mathrm{~mm}$ (Ducroquet et al. 2000). However, periodic monitoring of the population should not be dismissed because the fruit flies have no pre-established distribution pattern because of the presence of alternative hosts and different climatic conditions over the years (Aluja 1994). This is especially true for southern Brazil, with its large amounts of native fruits near commercial orchards.

A. fraterculus is the species with the highest distribution, abundance, and dominance in the temperate fruit producing regions in the States of southern Brazil (Garcia et al. 2011). Both feijoa orchards as well as temperate fruits are geographically distributed in the same regions and have similar reproductive periods, facilitating the multiplication of the fruit fly in these hosts.

Nora et al. (2000) recommend $25 \%$ grape juice for monitoring $A$. fraterculus in the State of Santa Catarina, Brazil. These authors reported that this bait stands out compared to other attractants because of the fermentation process. However, in our study, both the fresh grape juice as well as the aged grape juice did not provide effective results for capturing and monitoring $A$. fraterculus in the feijoa orchard (Table 1). Furthermore, Mangan and Thomas (2014) indicate that the rapid fermentation of grape juice results in unpleasant odors. This process possibly facilitates the capture of non-target insects such as Lepidoptera, common flies, wasps and bees. Although this data was not quantified in our work, we observed, in the field, that traps containing grape juice attractant captured large amounts of unwanted insects. This assertion is supported by Herrera et al. (2016), who found a major amount of unwanted insects in traps baited with grape juice in citrus orchards.

Hüntermann et al. (2013) found that hydrolyzed proteins used for the capture of $A$. fraterculus have a higher concentration of phenol after nine days of aging compared to grape juice. According to the authors, these compounds volatilize more quickly in grape juice, which can directly influence the loss of attractiveness and capture efficiency. Moreover, the fermented grape juice attractant may, from time to time, change its chemical odor and potentially change its attractiveness (Epsky et al. 2015).

The monitoring and quantification of specific pests in a culture is a necessary instrument for implementing any control strategy involving an integrated pest management approach (Aluja et al. 2012). Therefore, the monitoring and knowledge about the number of captured fruit flies serve as a basis for decision making about the control of these insects (Hickel 2008; Rosa et al. 2013). According to Nava

Table 1. Average ( \pm SEM) number of Anastrepha fraterculus adults captured per trap per day (FTD), percentage of females, and number of action thresholds in the feijoa orchard.

\begin{tabular}{lccc}
\hline \multirow{2}{c}{ Lures } & FTD \pm SEM & \% Females \pm SEM & $\begin{array}{c}\text { Action } \\
\text { thresholds }\end{array}$ \\
\cline { 2 - 3 } & $1.28 \pm 0.40 \mathrm{a}$ & $61.6 \pm 5.6 \mathrm{ab}$ & 9 \\
\hline CeraTrap® & $0.44 \pm 0.10 \mathrm{~b}$ & $48.8 \pm 4.7 \mathrm{~b}$ & 4 \\
Fresh grape juice & $0.30 \pm 0.10 \mathrm{bc}$ & $44.8 \pm 4.3 \mathrm{~b}$ & 2 \\
Grape Juice (7 days) & $0.12 \pm 0.04 \mathrm{c}$ & $66.6 \pm 4.2 \mathrm{a}$ & 0 \\
Grape Juice (14 days) & $0.00 \pm 0.00 \mathrm{c}$ & $0.0 \pm 0.0 \mathrm{c}$ & 0 \\
Control &
\end{tabular}

${ }^{1}$ Threshold for fruit flies in Brazil. Above 0.5 FTD, the control of fruit flies is recommended.

Means followed by different letters in the same column differed significantly (randomized block ANOVA,

Tukey's test, $\mathrm{P}<0.05$, non-transformed means presented). 
and Botton (2010), a major problem in fruit production losses is the fruit fly attacks where there is no detection by a pest monitoring system. In this case, an inadequate lure for capturing and monitoring populations of $A$. fraterculus can compromise the decision-making time, reflecting negatively on the production with the highest percentage of damaged fruits.

The detection of the action level for the control of $A$. fraterculus ( $>0.5$ FTD) in traps baited with Cera Trap ${ }^{\circledR}$ was observed 14 days before it was observed in the traps with fresh grape juice and 28 days before the observation in the traps with the grape juice with 7-day aging (Fig. 2). In addition to the reduced number of $A$. fraterculus captured, the 14-day aged grape juice did not provide an action threshold $(>0.5$ FTD) and there was no significant difference compared to the control during the production cycle. Similarly, Epsky et al. 2015 found no difference in the number of $A$. suspensa adults captured in traps baited with grape juice aged in the laboratory for 3, 6, and 9 days. These authors did not observe significant differences in the percentages of females captured for the treatments with grape juice at different ages.

Fruit juice is used in Brazil because of its low price and the fact that it is easily obtainable in the market. However, when comparing food baits, the hydrolyzed proteins showed more durability in their attractiveness in the field (Nunes et al. 2013). The percentage of fruit flies captured in fruit juice may be associated with the sugar concentration, which is directly related to the origin of the harvest and storage conditions of the juices (Santos et al. 2009).

The feijoa has a long harvest period, with both ripe fruits and fruits in development observed in the same tree. In hypothesis, fresh or aged grape juice does not present sufficient attractiveness because of high concentrations of volatiles emitted by mature feijoa fruits in harvesting periods or by decomposing fruits in the orchard, thereby reducing the effectiveness of the monitoring. The presence of different odors and mature fruit volatiles within the orchard is considered as a preponderant factor for the masking of lures baited with fruit juice (Cornelius et al. 2000; López-Guillén et al. 2010), which can become imperceptible to tephritids. In addition, the chemotactic behavior of fruit flies can be compromised in the presence of ripening fruit volatiles (Cornelius et al. 2000). Another hypothesis may be related to maturation anticipation or premature drop of fruits that are attacked by other insects, such as Conotrachelus psidii (Coleoptera: Curculionidae), with high incidence in the feijoa orchards in this region (Rosa et al. 2015). Decomposing feijoa fruits may also present high sugar concentrations which may be satisfying the food needs of $A$. fraterculus adults, thus justifying the low attraction and capture rates in traps baited with grape juice. On the other hand, fruit flies need to consume protein as adults for sexual maturation and ovarian development (Drew and Yuval 2000). Based on this, we may also explain the higher catch rate of $A$. fraterculus in traps baited with Cera Trap ${ }^{\circledR}$ in our study.

Management of fruit flies (Tephritidae) in Brazilian fruit farming is an increasing challenge. Effective lures for pest monitoring associated with specific tools for reducing the adult population, e.g. toxic baits, mass trapping, and biological control, can be used in combination for adequate control within the integrated management strategy, considering the required standards of the current market. The South Region of Brazil also distinguishes itself by the production of a wide variety of temperate fruit, such as apples, grapes, peaches, and plums. We recommend further studies to assess the validation of the Cera Trap ${ }^{\circledR}$ lure for capturing $A$. fraterculus in different fruits species.

In conclusion, fresh grape juice or grape juice at different aging stages showed deficiencies in monitoring and detecting the A. fraterculus population in feijoa orchards. Cera Trap ${ }^{\mathbb{B}}$ was a better lure for detecting $A$. fraterculus even in periods with low population densities. For this reason, Cera Trap ${ }^{\circledR}$ can be considered as an alternative for improving monitoring systems, thereby enabling greater accuracy for detecting $A$. fraterculus in orchards.

\section{Acknowledgements}

We would like to thank Mr. Jorge A. Borges for his technical assistance. We would also like to express our appreciation for the comments made by the reviewers of this paper.

\section{Literature cited}

ALBERTI, S.; BOGUS, G. M.; GARCIA, F. R. M. 2012. Flutuação populacional de moscas-das-frutas (Diptera, Tephritidae) em pomares de pessegueiro e maracujazeiro em Iraceminha, Santa Catarina. Revista Biotemas 25 (1): 53-58.

ALUJA, M. 1994. Bionomics and management of Anastrepha. Annual Review of Entomology 39 (1): 155-178.

ALUJA, M.; ORDANO, M.; GUILLEN, L.; ANDRULL, J. 2012. Understanding long-term fruit fly (Diptera: Tephritidae) population dynamics: implications for area-wide management. Journal of Economic Entomology 105 (3): 823-826.

BOTTON, M.; JUNIOR, R. M.; NAVA, D. E.; ARIOLI, C. J. 2012. Novas alternativas para o monitoramento e controle de Anastrepha fraterculus (Wied., 1830) (Diptera: Tephritidae) na fruticultura de clima temperado. In: Oliveira, A.F. de. 2012. Oliveira no Brasil: tecnologias de produção. Belo Horizonte: Epamig. 772 p.

CANGUSSU, J. A.; ZUCOLOTO, F. S. 1997. Effect of protein sources on fecundity, food acceptance, and sexual choice by Ceratitis capitata (Diptera: Tephritidae). Revista Brasileira de Biologia 57 (1): 611-618.

CORNELIUS, M. L.; DUAN, J. J; MESSING, R. H. 2000. Volatile host fruit odors as attractants for the Oriental fruit fly (Diptera: Tephritidae). Journal of Economic Entomology 93 (1): 93-100.

DREW, R. A. I.; YUVAL, B. 2000. The evolution of fruit fly feeding behavior. pp. 731-749. In: Aluja, M.; Norrbom, A. (Eds.). Fruit Flies. CRC, Boca Raton.

DUCROQUET, J. P. H. J.; HICKEL, E. R.; NODARI, R. O. 2000. Goiabeira Serrana (Feijoa sellowiana). Série Frutas Nativas, Jaboticabal: Funep. 66 p.

EPSKY, N. D.; GILL, M. A.; MANGAN, R. L. 2015. Grape juice as a bait for Anastrepha suspensa (Diptera: Tephritidae) and Zaprionus indianus (Diptera: Drosophilidae). Journal of Economic Entomology 108 (1): 2065-2073.

EPSKY, N. D.; KENDRA, P. E.; SCHNELL, E. Q. 2014. History and development of food-based attractants. In: Shelly, T. E.; Epsky, N.; Jang, E. B.; Reyes-Flores, J.; Vargas, R. I. Trapping and the detection, control, and regulation of tephritid fruit flies. Springer, Dordrecht. 638 p.

GARCIA, F. R. M.; NORRBOM, A. L. 2011. Tephritoid flies (Diptera, Tephritoidea) and their plant hosts from the state of Santa Catarina in southern Brazil. Florida Entomologist 94 (1): 151-157.

HEATH, R. R. 1993. Development of attractants for monitoring Caribbean fruit flies (Diptera: Tephritidae). Florida Entomologist 76 (2): 233-244.

HERRERA, F.; MIRANDA, E.; GÓMEZ, E.; PRESA-PARRA, E.; LASA, R. 2016. Comparison of hydrolyzed protein baits and 
various grape juice products as attractants for Anastrepha fruit flies (Diptera: Tephritidae). Journal of Economic Entomology 109: 161-166.

HICKEL, E. R. 2008. Pragas das fruteiras de clima temperado no Brasil: guia para o manejo integrado de pragas. Florianópolis: Epagri. 170 p.

HÜNTERMANN, J.; FOPPA, T.; NORA, H. 2013. Estudo da quantificação de fenóis em atrativos alimentares e sua relação com a eficácia na atração da mosca-das-frutas (Anastrepha fraterculus), em pereiras, em caçador-sc. Revista Interdisciplinar de Estudos em Saúde 2 (1): 23-26.

KOVALESKI, A. 2004. Pragas. In: Kovaleski, A. Maçã produção. Brasília, Embrapa, 169 p.

KOVALESKI, A.; RIBEIRO, L. G. 2002. Manejo de pragas na produção integrada de maçã. Bento Gonçalves: Embrapa Uva e Vinho. (Circular Técnica, 34).

KOVALESKI, A.; SUGAYAMA, R. L.; URAMOTO, K.; MALAVASI, A. 2000. Rio Grande do Sul. In: Malavasi, A.; Zucchi, R. A. Moscas-das-frutas de importância econômica no Brasil: conhecimento básico e aplicado. Ed. Holos, Ribeirão Preto, SP. 327 p.

LASA, R.; CRUZ, A. 2014. Efficacy of new commercial traps and the lure Cera trap ${ }^{\circledR}$ against Anastrepha obliqua (Diptera: Tephritidae). Florida Entomologist 97 (4): 1369-1377.

LASA, R.; VELÁZQUEZ, O. E.; ORTEGA, R.; ACOSTA, E. 2014. Efficacy of commercial traps and food odor attractants for mass trapping of Anastrepha ludens (Diptera: Tephritidae). Journal of Economic Entomology 107 (1): 198-205.

LASA, R.; HERRERA, F.; MIRANDA, E.; GÓMEZ, E.; ANTONIO, S.; ALUJA, M. 2015. Economic and highly effective trap-lure combination to monitor the Mexican fruit fly (Diptera: Tephritidae) at the orchard level. Journal of Economic Entomology 108 (1): 1637-1645.

LÓPEZ-GUILLÉN, G.; TOLEDO, J.; ROJAS, J. C. 2010. Response of Anastrepha obliqua (Diptera: Tephritidae) to fruit odors and protein-based lures in field trials. Florida Entomologist 93 (2): 317-318.

LUCKMANN, A. B.; ROSA, J. M. da.; BOFF, P. 2009. Danos e dispersão do gorgulho Conotrachelus sp. em goiabeira serrana (Acca sellowiana) sob monocultivo e ecossistemas "Capões". Revista Brasileira de Agroecologia 4 (1): 1224-1228.

MACHOTA-JUNIOR, R.; BORTOLI, L. C.; LOECK, A. E.; GARCIA, F. R. M.; BOTTON, M. 2013. Estratégia atrativa. Cultivar Hortaliças e Frutas 11 (81): 20-23.

MAHMOUDI, M.; EBRAHIMZADEH, M. A.; ABDI, M.; ARIMI, Y.; FATHI, H. 2015. Antidepressant activities of Feijoa sellowiana fruit. European Review for Medical and Pharmacological Sciences 19 (13): 2510-2513.

MANGAN, R. L.; THOMAS, D. B. 2014. Comparison of torula yeast and various grape juice products as attractants for Mexican fruit fly (Diptera: Tephritidae). Journal of Economic Entomology 107 (2): 591-600.

MARÍN, C.; BOTTA, A.; SIERRAS, N.; CARRIÓN, M.; PIÑOL, R. 2006. Cera Trap, un sistema eficaz y ecológico para el control de la mosca de la fruta. Fruticultura Professional 159 (33): 5760.

MALAVASI, A.; ZUCCHI, R. A.; SUGAYAMA, R. L. 2000. Biogeografia. In: Malavasi, A.; Zucchi, R. A. 2000. Moscasdas-frutas de importância econômica no Brasil: conhecimento básico e aplicado. Ed. Holos, Ribeirão Preto, SP. 327 p.

MONTEIRO, L. B.; MAY DE MIO, L.; MOTTA, A. C. V.; SERRAT, B. M.; CUQUEL, F. L. 2007. Avaliação de atrativos alimentares utilizados no monitoramento de mosca-das-frutas em pessegueiro na Lapa - PR. Revista Brasileira de Fruticultura 29 (1): $72-74$.

MULLER, C.; ARIOLI, C. J.; MASCARO, F. A.; BOTTON, M.; LOPES, J. R. S. 2013. Pragas da ameixeira no Brasil. In: Kretzchmar, A. A.; Rufato, L.; Pelizza, T. R. E. A cultura da ameixeira. Florianópolis, Udesc 160 p.
NASCIMENTO, E.; AMBROGI, B.; SOUTO, L. S.; VILASBÔAS, M.; UCHÔA, M. 2014. Efeito do Envelhecimento de isca na captura de moscas (Diptera: Brachycera) em área de Caatinga. EntomoBrasilis 7 (1): 1-4.

NAVA, D. E.; BOTTON, M. 2010. Bioecologia e controle de Anastrepha fraterculus e Ceratitis capitata em pessegueiro. Embrapa Clima Temperado. Documentos, 315. Pelotas: Embrapa Clima Temperado. 29 p.

NORA, I.; HICKEL, E. R.; PRANDO, H. F. 2000. Moscas-dasfrutas nos estados brasileiros: Santa Catarina. In: Malavasi, A.; Zucchi, R. A. Moscas-das-frutas de importância econômica no Brasil: conhecimento básico e aplicado. Ed. Holos, Ribeirão Preto, SP. 327 p.

NORA I.; HICKEL, E. R. 2002. Pragas da macieira. In: A cultura da macieira. Florianópolis, Epagri. 743 p.

NUNES, M. Z.; SANTOS, R. S.; BOFF, M. I. C.; ROSA, J. M. 2013. Avaliação de atrativos alimentares na captura de Anastrepha fraterculus (Wiedemann, 1830) (Diptera: Tephritidae) em pomar de macieira. Revista de la Facultad de Agronomía 112 (2): 91-96.

R Development Core Team. 2012. R: A language and environment for statistical computing, reference index version 2.15. R Foundation for statistical computing, Vienna, Austria.

ROSA, J. M. da; CARISSIMI BOFF, M. I.; GONÇALVES, P. A.; BOFF, P.; NUNES, M. Z. 2013. Aceite de andiroba (Carapa guianensis Aubl) en la captura de la mosca de las frutas (Anastrepha fraterculus Wiedemann), en Guayaba Serrana (Acca sellowiana (Berg) Burret). Idesia (Arica) 31 (1): 97-101.

SALLES, L. A. B. 1999. Efeito do envelhecimento e da decomposição do atrativo na captura de adultos de Anastrepha fraterculus (Wied.) (Diptera: Tephritidae). Revista Brasileira de Agrociência 5 (2): 147-148.

SANTOS, R. S. S.; KLESENER, D. F.; MEGIER, G. A. 2009. Dominadora. Revista Cultivar - Hortaliças e Frutas 8 (56): 25 27.

SCOZ, L. P.; BOTTON, M.; SILVEIRA, M. S.; PASTORI, L. P. 2006. Avaliação de atrativos alimentares e armadilhas para o monitoramento de Anastrepha fraterculus (Wiedemann, 1830) (Diptera: Tephritidae) na cultura do pessegueiro (Prunus persica (L.) Batsh). Idesia (Arica) 24 (2): 7-13.

SIERRAS, N.; MARIN, C.; CARRIÓN, M.; BOTTA, A.; PIÑOL, R. 2006. Biological solution for control of Ceratitis capitata by mass trapping. pp. 71. In: Proceeding of the 22nd annual meeting of the International Society of Chemical Ecology. Barcelona, Spain.

STEYSKAL, G. C. 1977. Pictorial key to species of the genus Anastrepha (Diptera: Tephritidae). Washington: The Entomological Society of Washington. $35 \mathrm{p}$.

TEIXEIRA, R.; RIBEIRO, L. G; BOFF, M. I. C.; BOFF, P.; ZANARDI, O. Z. 2010. Atratividade de iscas alimentares comerciais para mosca-das-frutas em pomar de macieira. Revista Agropecuária Catarinense 23 (1): 84-88.

THORP, G.; BIELESKI, R. 2002. Feijoas: Origins, cultivation and uses. Auckland, N.Z: Horticultural Research. Ed. David Bateman. 87 p.

VISSER, J. H. 1986. Host odor perception in phytophagous insects. Annual Review of Entomology 31 (1): 121-144.

WESTON, R. J. 2010. Bioactive products from fruit of the feijoa (Feijoa sellowiana, Myrtaceae): A review. Food Chemistry 121 (1): 923-926.

ZHANG, M.; WANG, D.; REN, S. X.; FAN, L. Z.; LIU, R. D. 2010. Effects of feijoa cutting diameter on seedling quality. Agricultural Journal 5 (3): 139-141.

ZUCCHI, R. A. 2000. Taxonomia. In: Malavasi, A.; Zucchi, R. A. 2000. Moscas-das-frutas de importância econômica no Brasil: conhecimento básico e aplicado. Ed. Holos, Ribeirão Preto, SP. $327 \mathrm{p}$.

ZUCCHI, R. A. 2007. Diversidad, distribución y hospederos del género Anastrepha en Brasil. In: Hernández-Ortiz, 
V. (Ed.). Moscas de la fruta en Latinoamérica (Diptera: Tephritidae): Diversidad, biología y manejo. México: S y G Editores. $167 \mathrm{p}$.

ZUCOLOTO, E. S. 2000. Alimentação e nutrição de moscasdas-frutas. In: Malavasi, A.; Zucchi, R. A. Moscas-das-frutas de importância econômica no Brasil: conhecimento básico e aplicado. Ed. Holos, Ribeirão Preto, SP. 327 p.
Suggested citation:

ROSA, J. M. da; ARIOLI, C. J.; PADILHA, A. C.; AGOSTINETTO, L.; BOTTON, M. 2017. Effect of food lures for monitoring of Anastrepha fraterculus (Diptera: Tephritidae) in Acca sellowiana (Myrtaceae). Revista Colombiana de Entomología 43 (2): 201-207. Julio - Diciembre 2017. ISSN 0120-0488.

Received: 24-Jan-2016 • Accepted: 2-Jun-2017 